\title{
Implementasi Metode Research \& Development Pada Pengembangan Pembelajaran Matematika Berbasis Multimedia
}

\author{
Linda Perdana Wanti ${ }^{1^{*}}$, Laura Sari ${ }^{2}$ \\ ${ }^{1,2}$ Program Studi Teknik Informatika, Politeknik Negeri Cilacap \\ 1,2Jl. Dr. Soetomo No.1 Sidakaya Cilacap, Indonesia \\ Email: linda_perdana@pnc.ac.id'1 ${ }^{1}$ laurasari@pnc.ac.id ${ }^{2}$
}

Info Naskah:

Naskah masuk: 9 Juli 2020

Direvisi: 13 Maret 2021

Diterima: 14 Maret 2021

\begin{abstract}
Abstrak
Matematika merupakan sebuah pelajaran yang masih menjadi momok menyeramkan bagi sebagian kalangan pelajar. Ada beberapa cara yang digunakan untuk membuat matematika menjadi menyenangkan untuk dipelajari. Salah satunya mengemas materimateri pada pelajaran matematika menjadi lebih atraktif dan menarik, apalagi untuk anak-anak hal ini dapat membuat mereka menjadi tertarik untuk belajar matematika. Pengembangan pembelajaran matematika berbasis multimedia interaktif menjadi salah satu alternatif yang dikembangkan dengan menggunakan metode research \& development. Metode ini diawali dengan menggali masalah, mengumpulkan data-data yang dibutuhkan, mendesain produk yang akan dikembangkan, memvalidasi desain produk, menguji coba pemakaian sistem yang akan dikembangkan, merevisi produk, menguji coba produk, merevisi desain produk dan produk apabila terdapat kesalahan atau kekurangan dan yang terakhir adalah memproduksi hasil produk secara masal. Penelitian ini bertujuan untuk mengembangkan sebuah pembelajaran matematika yang berbasis multimedia interkatif yang nantinya dapat dioptimasi untuk meningkatkan minat pelajar dalam mempelajari matematika dan digunakan untuk meningkatkan mutu pendidikan.
\end{abstract}

\section{Keywords:}

Mathematics

$\mathrm{R} \& \mathrm{D}$ method;

Interactive Learning;

Multimedia;

System Development

\begin{abstract}
Mathematics is a lesson that is still a frightening specter for some students. There are several methods used to make mathematics fun to learn. One of them is to package material in mathematics to be more attractive and interesting, especially for children this can make them become interested in learning mathematics. The developed using research \& development methods. This method begins by exploring the problem, collecting data needed, designing the product to be developed, validating the product design, testing the use of the system to be developed, revising the product, testing the product, revising the product and product design if there are errors or deficiencies and the last is mass production of product. This research aims to develop an interactive multimedia-based mathematics learning which can later be optimized to increase student interest in learning mathematics and be used to improve the quality of education.
\end{abstract}




\section{Pendahuluan}

Sistem pendidikan nasional adalah seluruh komponen pendidikan yang saling terkait secara terpadu untuk mencapai tujuan pendidikan nasional yaitu mengembangkan potensi peserta didik agar menjadi manusia yang beriman dan bertakwa kepada Tuhan Yang Maha Esa, berakhlak mulia, sehat,berilmu, cakap, kreatif, mandiri [1]. Banyak cara yang dapat ditempuh oleh pendidik untuk membuat siswa merasa tidak bosan dan tertantang dalam setiap pelajaran yang diikuti dengan melakukan inovasi atau terobosan baru dalam menyampaikan materi pelajaran. Beberapa caranya mulai dari membuat peserta didik nyaman dengan apa yang dia pelajari, mengembangkan bahan ajar yang sesuai dengan perkembangan teknologi ataupun dengan membuat pembelajaran semenarik mungkin dengan memanfaatkan teknologi yang ada.

Pemanfaatan teknologi untuk membuat materi-materi pelajaran yang disampaikan kepada siswa lebih bervariatif dan menarik salah satunya dengan membuat pembelajaran berbasis multimedia interaktif yang nantinya dapat diimplementasikan sesuai dengan kebutuhan siswa. Pada penelitian kali ini media pembelajaran berbasis multimedia interaktif yang akan dibuat adalah untuk mata pelajaran matematika, karena selama ini permasalahan klasik yang sering dihadapi adalah matematika masih dianggap mata pelajaran yang susah untuk dimengerti dan memerlukan perhatian khusus dalam mempelajarinya oleh sebagian siswa disekolah. Untuk materi pelajarannyapun yang akan dibahas pada penelitian ini dikhususkan pada mata pelajaran siswa kelas VI SD. Materi pelajaran siswa kelas VI SD dipilih karena materi-materi pada jenjang ini merupakan permulaan untuk naik ke jenjang yang lebih tinggi.

Tetapi ternyata pemanfaatan teknologi belum menyentuh sepenuhnya di SD Negeri Sokaraja Kulon 1, dimana tersedianya fasilitas pendukung pembelajaran di kelas tidak disertai dan diimbangi dengan media pembelajaran interaktif khususnya untuk pembelajaran mata pelajaran matematika. Pada tahun 2019 pembelajaran yang dilakukan di SD Negeri Sokaraja Kulon 1 masih bersifat konvensional dimana materi diberikan secara langsung oleh guru kelas untuk semua mata pelajaran, kecuali mata pelajaran agama disampaikan oleh guru agama dan mata pelajaran olahraga disampaikan oleh guru olahraga. Siswa kelas VI SD Negeri Sokaraja Kulon 1 mendapatkan materi matematika selama 2 semester secara konvensional.

Beberapa penelitian yang pernah dilakukan antara lain penelitian oleh Ghasa, dkk yang membuat pembelajaran berbasis multimedia interktif pada mata pelajaran sains untuk siswa SD. Pengembangan pembelajaran ini menggunakan metode APPED yang dimulai dengan menganalisis pada penelitian awal, perancangan desain pembelajaran, dilanjutkan dengan produksi pembelajaran berbasis multimedia interaktif, kemudian tahap evaluasi untuk mengetahui apakah pembelajaran yang dibuat sudah sesuai dengan perancangan desain di awal proses, dan ketika evaluasi sudah dikerjakan, tahap akhir dari model ini adalah diseminasi produk pembelajaran yang telah jadi.
Hasil dari penelitian ini adalah produk pembelajaran berbasis multimedia yang teah dikembangkan dan alyak untuk digunakan tenaga pendidik yang berberntuk CD Interkatif Tata Surya Kit-A dan dapat diterapkan untuk pembelajaran anak kelas VI SD [2].

Penelitian yang kedua dilakukan untuk meningkatkan pemahaman siswa kelas XII SMA terhadap materi bioteknologi modern dengan mengembangkan pembelajaran berbasis multimedia interaktif oleh sri Riani, dkk. Materi bioteknologi memerlukan pemahaman yang membutuhkan waktu yang relatif lebih panjang dibandingkan dengan mata pelajaran yang lainnya karena materi ini disampaikan lebih banyak bersifat aplikatif. Model yang digunakan untuk pengembangan perangkat pembelajaran berbasis mulitimedia interaktif ini adalah model R \& D. Hasil dari penelitian ini adalah produk pembelajaran berbasis multimedia interaktif yang telah diujicobakan dan sudah melewati tahapan-tahapan evaluasi yang dilakukan oleh beberapa ahli yaitu ahli materi, ahli media dan beberapa siswa yang ikut dalam tahapan proses uji coba [3].

Penelitiaan selanjutnya oleh Novita, dkk yang melakukan penelitian untuk mengembangkan metode pembelajaran geografi pada materi sumber daya alam di kelas XI SMA jurusan IPS. Materi geografi yang didapat siswa lebih banyak berupa definisi sebuah konsep dan diakhiri dengan latihan soal. Tahapan pengembangan pembelajaran ini dimulai dengan menganalisis situasi dan kebutuhan. Kemudian dilanjutkan dengan mengembangkan pembelajaran geografi sesuai dengan kebutuhan yang telah dideskripsikan sebelumnya. Setelah tahapan pengembangan selesai maka produk diuji coba untuk mengetahui kekurangan dan penambahan modul-modul pada produk tersebut. Setelah produk diuji coba dan divalidasi oleh tim ahli dan ternyata $77.93 \%$ produk tersebut layak untuk digunakan sebagai media pembelajaran siswa kelas XI SMA [4].

Perbedaan penelitian ini dengan penelitian yang sudah pernah dilakukan adalah materi yang akan dikembangkan berbasis multimedia interaktif adalah matematika untuk siswa SD sebagai persiapan untuk pemahaman yang lebih baik untuk dapat naik tingkat ke jenjang selanjutnya. Model yang diadaptasi untuk mengembangkan dan menghasilkan sebuah perangkat pembelajaran berbasis multimedia interaktif adalah model R\&D [5]. Model R \& D dipilih karena dianggap paling sesuai dengan penelitian yang dilakukan sekarang dan hasil akhir yang diperoleh dari penelitian ini berupa produk multimedia interaktif. Kesesuaian model pengembangan dengan sistem yang dikembangkan menjadi salah satu hal yang penting karena langkah-langkah atau tahapan proses dapat maksimal [6]. Model R \& D dioptimasi pada pengembangan media pembelajaran berbasis multimedia interaktif untuk materi matematika kelas IV SD karena setiap langkah yang ada pada model $\mathrm{R}$ \& $\mathrm{D}$ ini sesuai dengan pengembangan pembelajaran ini dan juga agar hasil akhir produk yang dihasilkan dapat meningkatkan potensi siswa terhadap materi tersebut sehingga secara tidak langsung juga meningkatkan prestasi siswa serta meningkatkan pendidikan nasional secara global. 
Dengan adanya model pembelajaran berbasis multimedia interkatif mata pelajaran matematika untuk siswa kelas VI sekolah dasar, diharapkan mampu menumbuhkan dan meningkatkan minat belajar siswa dan mempersiapkan siswa ke jenjang yang lebih tinggi yaitu pendidikan ditingkat menengah pertama yang tentunya materi matematika yang disampaikan akan lebih mendalam. Bagi guru sekolah dasar, khusunya guru kelas VI, model pembelajaran berbasis multimedia interaktif ini memberikan variasi model pembelajaran kepada siswa sebagai bentuk pemanfaatan teknologi dalam mendidik dan menyampaikan materi mata pelajaran matematika.

\section{Metode}

\subsection{Multimedia yang diusulkan}

Multimedia merupakah sebuah pemanfaatan media komputer untuk mempresentasikan sebuah media pembelajaran yang menggabungkan beberapa elemen media seperti grafik, teks, animasi, video dan audio [7] Sedangkan pemanfaatan multimedia interaktif dapat digunakan untuk mempermudah siswa dalam memahami setiap detail mata pelajaran yang disampaikan oleh pendidik dalam proses belajar mengajar. Pemanfaatan multimedia interaktif secara signifikan dapat meningkatkan hasil belajar siswa [8]. Multimedia interaktif dapat dikembangkan sesuai dengan kebutuhan di lapangan untuk disesuaikan dengan materi-materi yang memang perlu dibuatkan pengembangan pembelajaran [9].

Penyajian sebuah materi dapat diperjelas dengan bantuan multimedia dengan berbagai manfaat yang melekat pada multimedia itu sendiri seperti untuk mengatasi keterbatasan ruang waktu, penyajian materi lebih interaktif yang menggabungkan audio dan video, dan yang paling penting dapat mengatasi kebosanan siswa akan materi yang disampaikan secara konvesional dan hanya mengandalkan visual saja [10]. Manfaat multimedia interaktif yang lain antara lain adalah materi-materi yang sifatnya abstrak maka dapat disajikan dengan lebih konkret, dan siswa dapat mengamati kejadian dalam media dalam bentuk simbol dan berperan aktif dalam proses belajar mengajat sehingga terjalin komunikasi dua arah antara pendidik dan peserta didik [11]. Multimedia interatif yang dikemas dengan animasi naik itu animasi dua dimensi atau animasi tiga dimensi dapat memperjelas penyajian materi yang disampaikan sehingga proses belajar emngajar menjadi semakin lancar [12]. Dampaknya secara signifikan dapat, menimbulkan motivasi untuk lebih banyak mempelajari materi-materi selanjutnya dan memungkinkan peluang untuk belajar secara mandiri dan pada akhirnya dapat meningkatkan prestasi belajar siswa [13].

\subsection{Metode Pengembangan Sistem}

Metode pengembangan sistem yang digunakan untuk mengembangkan pembelajaran berbasis multimedia interaktif adalah metode research \& development $(\mathrm{R} \& \mathrm{D})$. Tahapan proses pada metode ini dijelaskan pada Gambar 1. Berdasarkan pada gambar 1, tahapan prosesnya adalah tahapan pertama menggali masalah yang dihadapi dan menemukan solusi atas permasalahan yang dihadapi serta mencari data yang digunakan untuk menyelesaikan masalaha yang dihadapi [14].

Pada penelitian ini data-data tentang potensi masalah atau masalah yang dihadapi didapat dari hasil observasi dan wawancara yang dilakukan dengan pihak sekolah baik guru pengajar maupun siswa kelas VI SD Negeri Sokaraja Kulon 1. Data pendukung didapat dengan studi literature dengan mencari data pendukung di internet maupun buku yang mendukung tentang tema yang diangkat yaitu pengembangan pembelajaran berbasis multimedia interaktif untuk materi matematika siswa SD kelas VI. Data yang didapatkan selama proses wawancara dan observasi adalah data materi mata pelajaran matematika kelas VI semester 1 dan semester 2, data siswa kelas VI SD Negeri Sokaraja Kulon 1, dan data hasil pembelajaran siswa kelas VI SD Negeri Sokaraja Kulon 1.

Tahapan berikutnya adalah merencanakan form awal untuk produk yang akan dibuat dan mendesain rancangan awal untuk produk yang dibuat [15]. Rancangan awal dari produk yang dibuat didasarkan pada penilaian terhadap

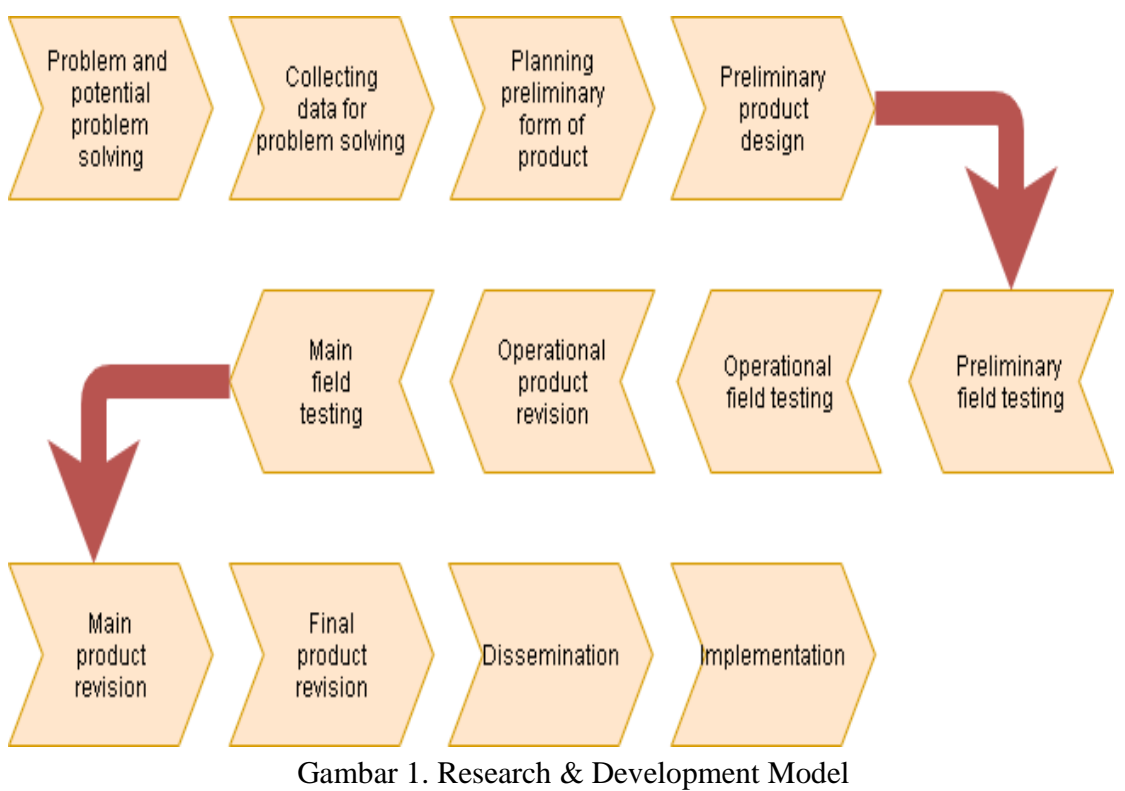


produk lama atau proses lama sehingga ditemukan kelemahan atau kekurangan yang dapat diselesaikan dengan pembuatan produk baru. Pembelajaran konvensional dirinci detail kelemahan yang dapat diatasi dengan pembuatan produk pembelajaran berbasis multimedia interaktif. Untuk pembelajaran konvensional sendiri, feedback dari siswa kelas VI ditelaah untuk membuat rancangan awal untuk mengatasi kekurangan tersebut.

Tahapan selanjutnya adalah validasi desain awal dan evaluasi desain awal untuk dapat melanjutkan ke pembuatan desain operasional yang nantinya desain tersebut digunakan untuk pembuatan desain operasional akhir produk yang dikembangkan sebelum produk tersebut diuji coba kepada ahli dibidang media, ahli dibidang matematika dan end user [16]. Validasi desain awal sebagai bagian pertama dari pembuatan desain produk sebelum desain tersebut dilanjutkan ke tahapan desain operasional produk sebagai desain akhir yang nantinya juga melewati tahap validasi desain operasional. Desain awal pembelajaran berbasis multimedia interaktif dibuat berdasarkan sketsa yang dibuat berdasarkan data awal. Setelah sketsa tersebut tervalidasi maka akan dibuat story board dari materi matematika berbasis multimedia interaktif. Story board yang telah selesai juga divalidasi dan diuji coba kepada ahli di bidang media, ahli dibidang matematika, siswa kelas VI SD dan guru kelas VI SD Negeri Sokaraja Kulon 1.

Untuk tahapan terakhir pada model research and development adalah perbaikan produk setelah uji coba dengan memperhatikan masukan dari ahli yang dilibatkan serta end user, sebelum produk tersebut dibuat secara masal untuk dapat diimplementasikan [17]. Hasil perbaikan story board yang telah diuji coba dengan memperhatikan feedback dari para penguji coba digunakan untuk proses produksi masal produk pada tahap akhir dari metode Research \& Development sebelum diimplementasikan. Produk tersebut dapat diimplementasikan sebagai hasil luaran dari penelitian yang dilakukan yang berupa produk pembelajaran berbasis multimedia interakif materi matematika kelas VI SD. Selain pembuatan produk dengan perbaikan story board tahapa finalisasi artinya sudah tidak ada lagi perbaikan story board dari end user yaitu siswa dan guru kelas VI SD Negeri Sokaraja Kulon 1, nantinya produk pembelajaran berbasis multimedia interaktif ini akan dilakukan diseminasi yaitu sosialisasi produk hasil luaran penelitian berupa model pembelajaran berbasis multimedia interaktif kepada masyarakat luas khususnya siswa kelas VI. Proses diseminasi dan implementasi ini sebagai bentuk finalisasi terhadap tahapan akhir metode Research \& Development pada penelitian ini.

\section{Hasil dan Pembahasan}

Materi yang dibahas pada pengembangan pembelajaran ini dibagi menjadi dua bagian yaitu untuk materi semester 1 dan materi semester 2. Materi semester 1 meliputi bilangan bulat, pengukuran debit, geometri dan pengolahan data yang dilengkapi dengan latihan soal untuk setiap materi tersebut. Sedangkan materi untuk semester 2 meliputi pecahan, sistem koordinat dan pengolahan data 2 yang juga dilengkapi dengan latihan soal untuk setiap materi tersebut.
Untuk latihan soal setiap materi pada semester 1 maupun semester 2 dibuat dengan bentuk soal pilihan ganda. Setelah siswa telah menyelesaikan soal latihan maka siswa dapat melihat skor yang diperoleh. Gambar 2 menunjukkan struktur navigasi dari produk pembelajaran berbasis multimedia interaktif.

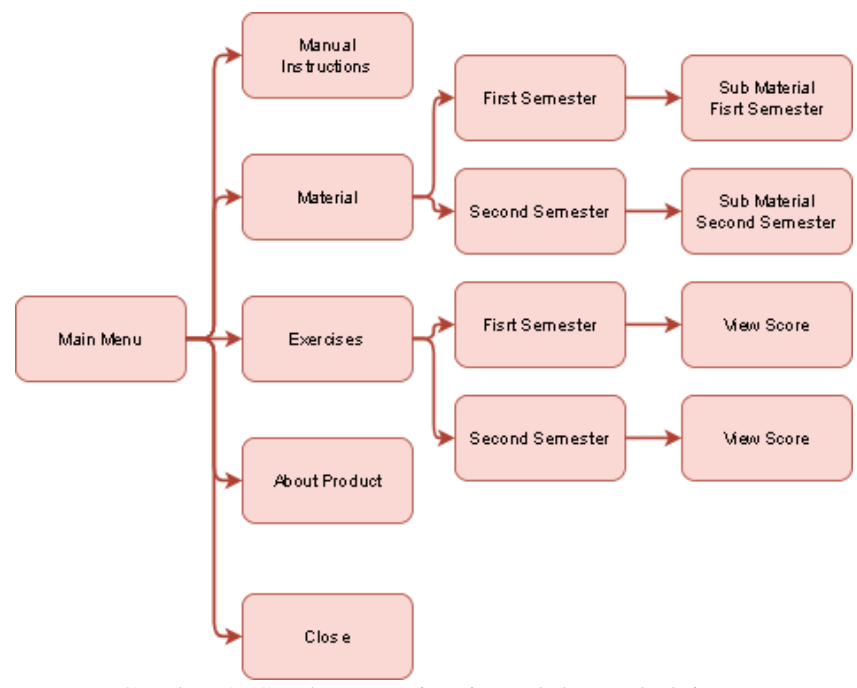

Gambar 2. Struktur Navigasi Produk Pembelajaran

Pada Gambar 2 sudah terlihat jelas pada menu utama ada lima modul yang dapat dibreakdown yaitu petunjuk penggunaan tentang produk pembelajaran matematika berbasis multimedia interkatif, kemudian ada materi yang dibagi menjadi dua bagian yaitu semester satu dan semester dua beserta sub materi untuk masing-masing semester. Modul ketiga adalah latihan soal yang juga dibagi menjadi dua bagian yaitu semester satu dan semester dua. Selanjutnya ada modul keempat tentang produk pembelajaran matematika berbasis multimedia sedangkan modul yang terakhir adalah close untuk keluar dari pembelajaran matematika berbasis multimedia ini.

Pada Gambar 3 merupakan implementasi dari halaman material yang terdiri dari dua semester, semester satu dan semester dua. Pada gambar 3 tersebut terlihat materi-materi yang ada pada semester satu dan materi yang ada pada semester dua.

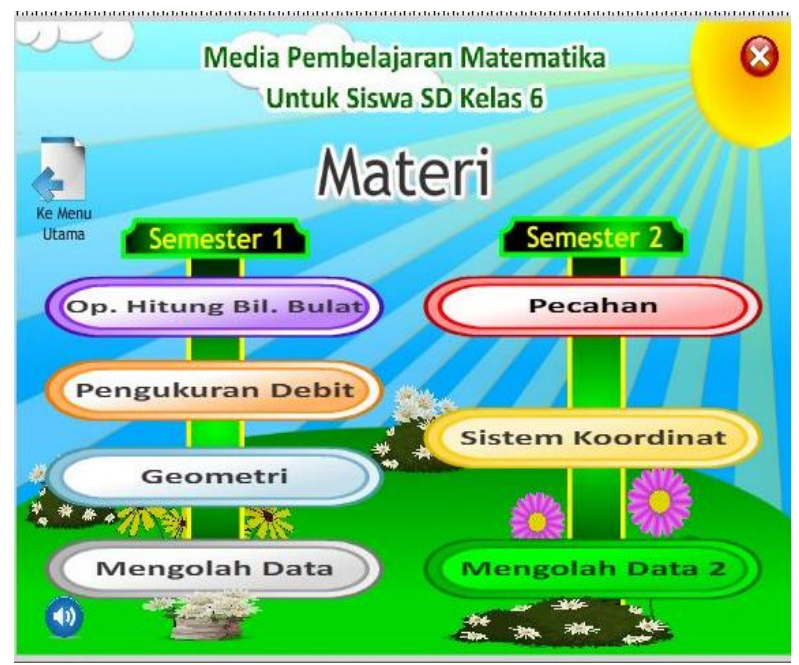

Gambar 3. Halaman Menu Materi 


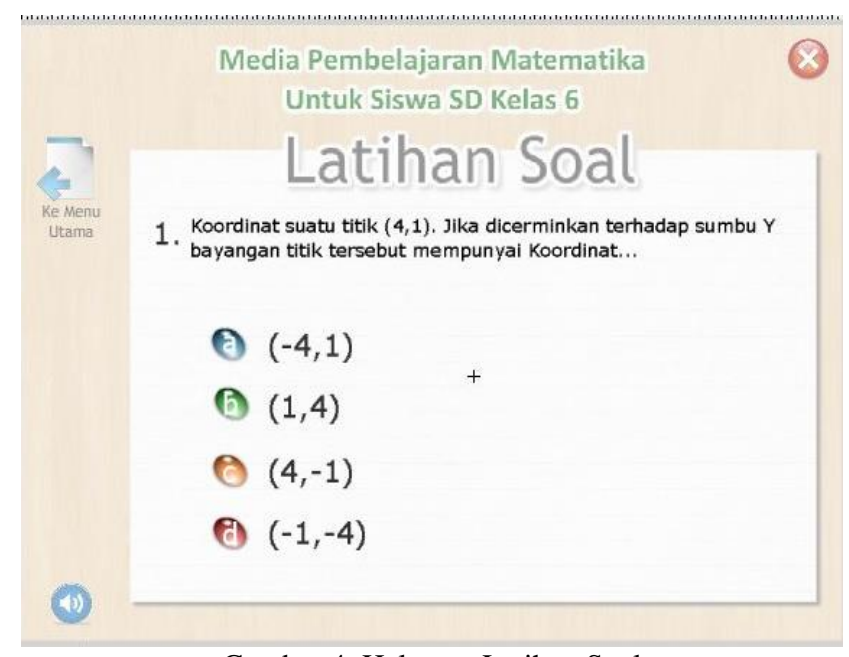

Gambar 4. Halaman Latihan Soal

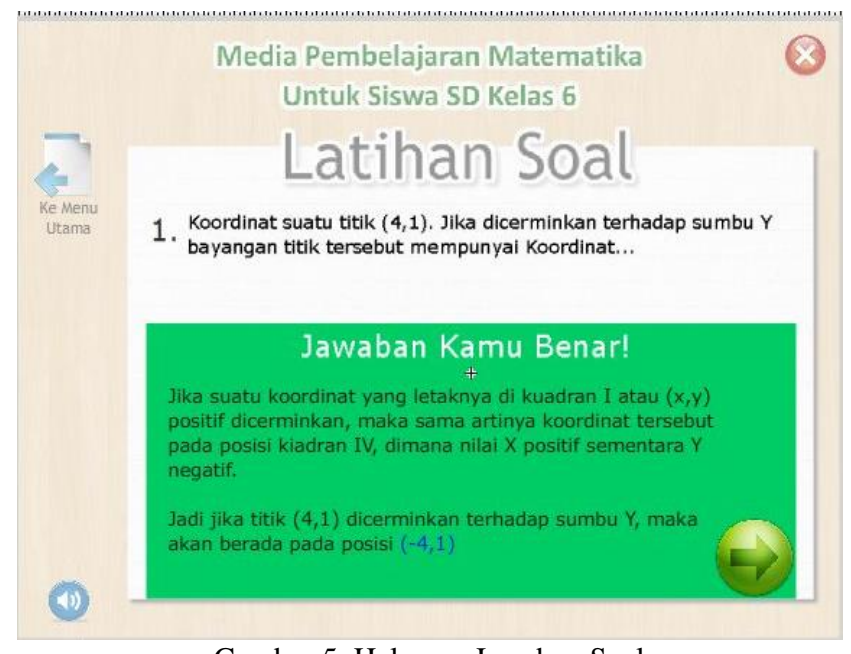

Gambar 5. Halaman Jawaban Soal

Gambar 4 adalah hasil implementasi dari modul tiga yaitu latihan soal yang berjenis soal pilihan ganda yang menunjukkan latihan soal untuk materi koordinat yang ada pada semester dua. Pada Gambar 5 menunjukkan jawaban dari soal pada gambar 4 yang disertai dengan penjelasan apabila memilih jawaban yang benar. Penjelasan tersebut disesuaikan dengan jenis soal. Soal dipilih yang berjenis pilihan ganda karena pengecekan jawaban yang dibuat berdasarkan pilihan jawaban yang benar apakah opsi A, atau opsi B, atau C atau opsi D. Jawaban dicek antara kunci jawaban materi tertentu dengan jawaban yang dipilih oleh user dan ditampilkan apakah bernilai benar atau bernilai salah.

\subsection{Evaluasi}

Hasil dari evaluasi yang dilakukan terhadap produk pembelajaran matematika kelas VI SD berbasis multimedia interkatif yang dinilai dari beberapa segi seperti segi fungsionalitas modul-modul yang ada pada pembelajaran tersebut, kemudian segi tampilan seperti kesesuaian warna yang digunakan pada animasi pembelajaran berbasis multimedia interaktif dan dari segi konten pembelajaran tersebut yang sesuai dengan materi yang dibahas yaitu materi semester 1 dan materi semester 2 mata pelajaran matematika kelas VI SD. Evaluasi dilakukan oleh beberapa ahli yang terlibat seperti ahli media, ahli instruksional dan ahli di bidang materi. Hasil penilaian evaluasi dapat dilihat pada Tabel 1 .

Tabel 1. Hasil Evaluasi

\begin{tabular}{clc}
\hline No. & \multicolumn{1}{c}{ Fungsi } & Status \\
\hline 1. & $\begin{array}{l}\text { Tombol yang ada pada setiap halaman } \\
\text { modul dapat digunakan dengan baik }\end{array}$ & Berhasil \\
2. & $\begin{array}{l}\text { Tidak terjadi eror/kesalahan pada } \\
\text { setiap media, baik media suara } \\
\text { maupun media gambar }\end{array}$ & Berhasil \\
3. & $\begin{array}{l}\text { Media berjalan dengan lancer pada } \\
\text { saat dijalankan }\end{array}$ & Berhasil \\
4. & \multicolumn{1}{c}{ Tampilan } \\
5. & $\begin{array}{l}\text { Jenis dan ukuran huruf yang } \\
\text { digunakan sudah sesuai }\end{array}$ & Sesuai \\
6. & $\begin{array}{l}\text { Warna dan tata letak tombol-tombol } \\
\text { yang digunakan sesuai dengan }\end{array}$ & Sesuai \\
kemauan dan kebutuhan end user & \\
7. & \multicolumn{1}{c}{$\begin{array}{l}\text { Materi pembelajaran sudah benar } \\
\text { Tata tulis dan ejaan yang digunakan } \\
\text { baik }\end{array}$} & Valid \\
\end{tabular}

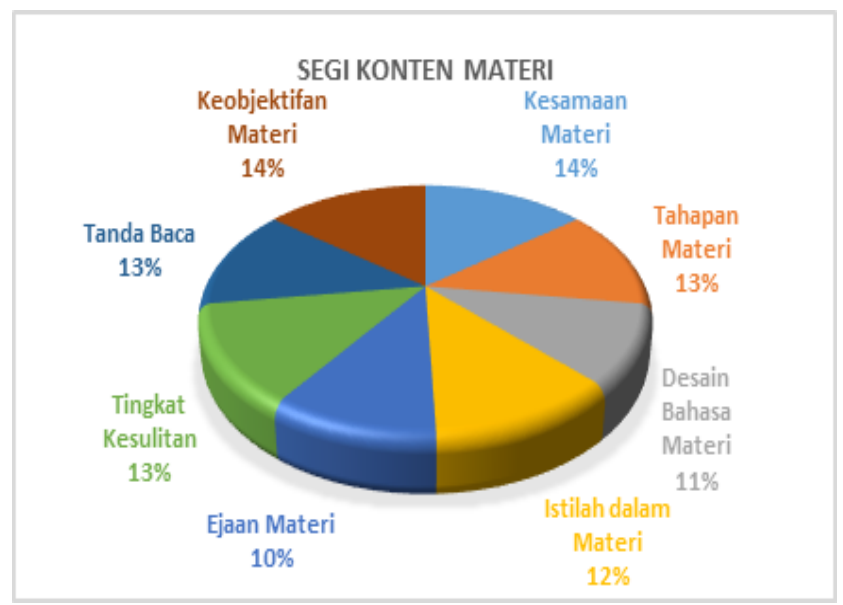

Gambar 6. Hasil Validasi Penilaian Oleh Ahli Materi

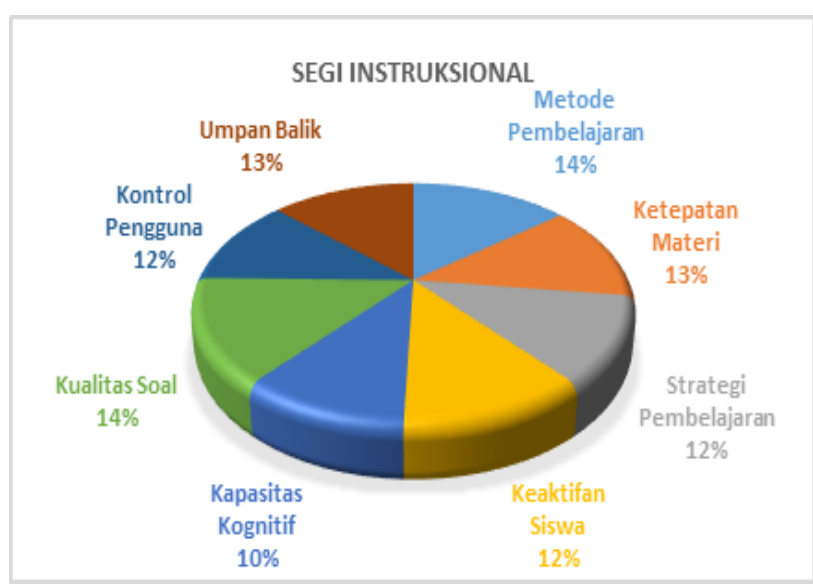

Gambar 7. Hasil Validasi Penilaian Oleh Ahli Instruksional 


\section{a) Pengujian Alpha}

Pengujian alpha dilakukan dengan melibatkan berbagai ahli dibidang masing-masing seperti ahli dibidang materi, ahli dibidang instruksional dan ahli dibidang media. Keterlibatan beberapa ahli tersebut untuk memvalidasi produk pembelajaran yang dihasilkan. Beberapa ahli yang terlibat dalam proses tersebut berasala dari Guru Kelas VI SD Negeri Sokaraja Kulon 1 memberikan penilaian validasi terhadap produk pembelajaran berbasis multimedia interaktif mata pelajaran matematika kelas VI yang disajikan pada Gambar 6. Penilaian hasil validasi yang kedua diberikan oleh ahli instruksional yang meliputi 8 kriteria yang ditunjukkan pada gambar 7 berupa grafik beserta dengan nilai per kriteria instruksional yang ditetapkan oleh ahli instruksional terhadap produk pembelajaran berbasis multimedia interaktif adalah seperti pada Gambar 7.

Untuk penilaian yang terakhir adalah penilaian validasi yang diberikan oleh ahli media yang disajikan pada Gambar 8.

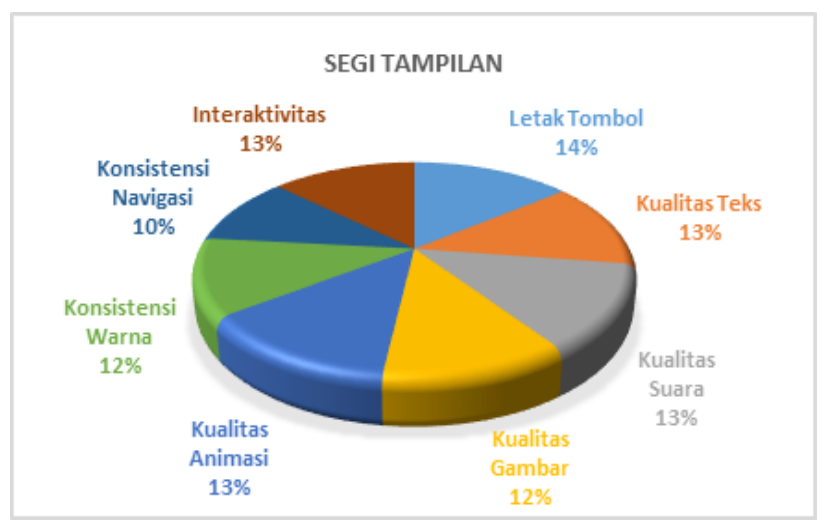

Gambar 8. Hasil Validasi Penilaian Oleh Ahli Media

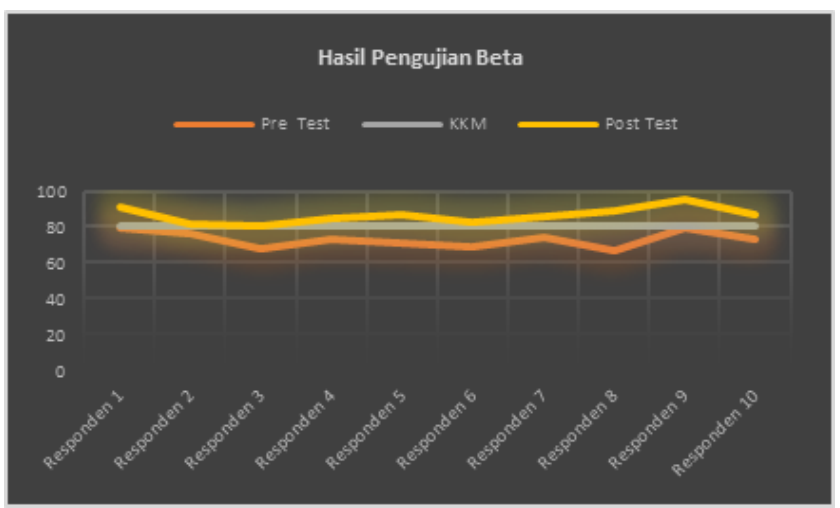

Gambar 9. Hasil Pengujian Beta

\section{b) Pengujian Beta}

Pengujian beta dilakukan kepada beberapa responden yang menguji coba produk pembelajaran berbasis multimedia interaktif ini yaitu 10 siswa kelas VI SD Negeri Sokaraja Kulon 1. Pengujian dilakukan dengan menggunakan materi beberapa semester 1 dan semester 2 . Nilai keriteria ketuntasan minimal yang ditetapkan adalah 80, diperlihatkan pada Gambar 9
Dari gambar 9 tersebut dapat diambil kesimpulan bahwa produk pembelajaran berbasis multimedia interaktif berpengaruh signifikan terhadap hasil evaluasi pembelajaran siswa yang mengalami peningkatan setelah dilakukan pre test dan post test terhadap nilai krteria ketuntasan minimal (KKM).

\section{Kesimpulan}

Penelitian ini telah berhasil menghasilkan produk pembelajaran matematika untuk siswa kelas VI SD berbasis multimedia interaktif. Produk ini nantinya akan diproduksi secara masal sebagai tahapan akhir dari metode research \& development dan diimplementasikan di sekolah yang membutuhkan dalam bentuk CD interaktif. Kekurangan dari penelitian ini adalah latihan soal masih hanya berjenis pilihan ganda, untuk penelitian selanjutnya dapat dikembangkan lagi produk pembelajaran berbasis multimedia interaktif dengan latihan soal berbentuk essay.

\section{Daftar Pustaka:}

[1] Republik Indonesia, UU No 20 Tahun 2003 Tentang Sistem Pendidikan Nasional. 2003, pp. 1-33.

[2] G. F. 'Alam, H. M. Az-Zahra, and R. I. Rokhmawati, "Pengembangan Media Pembelajaran Berbasis Multimedia Interaktif pada Mata Pelajaran Sains Materi Tata Surya Menggunakan Model APPED (Studi Kasus: SD Brawijaya Smart School)," J. Pengemb. Teknol. Inf. dan Ilmu Komput., vol. 3, no. 4, pp. 3832-3837, 2019.

[3] S. Riani, I. Hindun, and M. A. Krisno Budiyanto, "Pengembangan Media Pembelajaran Berbasis Multimedia Interaktif Untuk Meningkatkan Pemahaman Materi Bioteknologi Modern Siswa Kelas Xii Sma," J. Pendidik. Biol. Indones., vol. 1, no. 1, pp. 9-16, 2015.

[4] N. Sariani, C. Muryani, and M. G. Rindarjono, "Pengembangan Modul Pembelajaran Geografi Berbasis Peduli Lingkungan untuk Meningkatkan Sikap Peduli Lingkungan Siswa pada Materi Sumber Daya Alam di Kelas XI IPS SMA Bina Utama Pontianak," J. GeoEco, vol. 3, no. 1, pp. 40-46, 2017.

[5] S. Rabiah, "Penggunaan Metode Research and Development dalam Penelitian Bahasa Indonesia di Pergurtuan Tinggi," Univ. Muslim Indones., vol. 1, no. April 2015, pp. 1-7, 2015.

[6] Hanafi, "Konsep Penelitian R \& D Dalam Bidang Pendidikan," Saintifika Islam. J. Kaji. Keislam., vol. 4, no. 2, pp. 129-150, 2017.

[7] F. M. A. Khan and M. Masood, "The Effectiveness of an Interactive Multimedia Courseware with Cooperative Mastery Approach in Enhancing Higher Order Thinking Skills in Learning Cellular Respiration," Procedia - Soc. Behav. Sci., vol. 176, pp. 977-984, 2015.

[8] M. A. Lindner, A. Eitel, J. Barenthien, and O. Köller, “An integrative study on learning and testing with multimedia: Effects on students' performance and metacognition," Learn. Instr., no. December 2017, 2018.

[9] K. Chachil, A. Engkamat, A. Sarkawi, and A. R. A. Shuib, "Interactive Multimedia-based Mobile Application for Learning Iban Language (I-MMAPS for Learning Iban Language)," Procedia - Soc. Behav. Sci., vol. 167, pp. 267273, 2015

[10] C. W. Park, D. gook Kim, S. Cho, and H. J. Han, "Adoption of multimedia technology for learning and gender difference," Comput. Human Behav., vol. 92, pp. 288-296, 2019. 
[11] N. Watts, "A learner-based design model for interactive multimedia language learning packages," System, vol. 25, no. 1, pp. 1-8, 1997.

[12] S. Misra, B. Banerjee, and B. E. Wolfinger, "A learning automata-based uplink scheduler for supporting real-time multimedia interactive traffic in IEEE 802.16 WiMAX networks," Comput. Commun., vol. 35, no. 15, pp. 18711881, 2012.

[13] J. Li, P. D. Antonenko, and J. Wang, "Trends and issues in multimedia learning research in 1996-2016: A bibliometric analysis," Educ. Res. Rev., vol. 28, no. November 2018, p. 100282, 2019.

[14] I. Kabashkin and J. Lučina, "Development of the model of decision support for alternative choice in the transportation transit system," Transp. Telecommun., vol. 16, no. 1, pp.
61-72, 2015.

[15] Q. Bin Liu, S. Gao, B. F. Guo, H. Liu, Y. Z. Feng, and H. Xia, "Research and development of movie social system," Procedia Comput. Sci., vol. 166, pp. 154-159, 2020.

[16] H. Sato, T. Aoki, H. Ohashi, and X. L. Yan, "Research and development for safety and licensing of HTGR cogeneration system," Nucl. Eng. Des., vol. 360, no. December 2019, p. 110493, 2020.

[17] H. Liu, Y. Liu, H. Wang, J. Yang, and X. Zhou, "Research on the coordinated development of greenization and urbanization based on system dynamics and data envelopment analysis__ A case study of Tianjin," $J$. Clean. Prod., vol. 214, pp. 195-208, 2019. 